\title{
Diet selection of mountain lions in southeastern Arizona
}

\author{
STAN C. CUNNINGHAM, CARL R. GUSTAVSON, AND WARREN B. BALLARD
}

Stan Cunningham and Carl Gustavson, at the time of the research, were research biologists, and Warren Ballard was research program supervisor, Research Branch, Arizona Game and Fish Department, 2221 W. Greenway Road, Phoenix Ariz. 85023.

\begin{abstract}
Prey selection by mountain lions (Puma concolor) in the Aravaipa-Klondyke area in southeastern Arizona was studied from February 1991 to September 1993. Overall diet as determined from frequency of occurrence in 370 scats was $48 \%$ deer (Odocoileus virginianus cousi and $O$. hemionus combined), $34 \%$ cattle, $17 \%$ javelina (Tayassu tajacu), $6 \%$ rabbit (Sylvilagus spp. and Lepus californicus combined), $4 \%$ rodent, and $2 \%$ desert bighorn sheep (Ovis canadensis mexicanus). With respect to biomass consumed, cattle composed $44 \%$, deer $40 \%$, javelina $10.9 \%$, rabbits $2.9 \%$, and rodents $0.02 \%$. Based on mean weights of prey consumed, the proportion of individuals killed and eaten changed to rabbits $52.7 \%$, deer $16.3 \%$, rodents $12 \%$, javelina $10 \%$, cattle $8 \%$, and desert bighorn sheep $0.5 \%$. Mountain lions selected deer less frequently than their availability would suggest, selected calves slightly more than their availability, and javelina as expected. We speculated that lions selected calves because they were more vulnerable to predation than deer.
\end{abstract}

Key Words: prey availability, cattle, diet selection, Puma concolor, javelina, mule deer, white-tailed deer.

Livestock have been preyed upon by mountain lions since they were first introduced from Europe (Barnes 1960), and livestock loss remains a major rationale for controlling them. Arizona reportedly has some of the highest mountain lion kill rates on cattle in the United States (Christensen and Fischer 1976, Nowak 1976, Anderson 1983). Killing mountain lions that prey on livestock (i.e., depredation control) remains a legal, though controversial practice, and accounts for a substantial portion of the human-caused mortalities of Arizona mountain lions (Cunningham et al. 1995).

During 1987, the Aravaipa-Bonita Cattle Growers Association of southeast Arizona reported that mountain lions had killed more calves than historically. Consequently, they contracted with the Animal and Plant Health Inspection Service (APHIS), U.S. Department of Agriculture, to control

This manuscript is dedicated to the memory of Dr. Carl R. Gustavson, an excellent biologist and better friend. This study was funded by the Federal Aid in Wildlife Restoration Act Project W-78-R. Constructive criticism on earlier drafts was provided by J. Truett, B. Wakeling, P. Beier, R. Schwiensburg, K. Logan, and J. deVos. We thank K. Sargent, J. Yarchin, and J. Simmons who were involved in data collection. We also thank the San Carlos Apache Nation for allowing us to conduct research on their land.

Manuscript accepted 24 Aug. 1998.

\section{Resumen}

Presa seleccionada por el León de Montaña (Puma concolor) en el Sureste del Estado de Arizona en el area de Aravaipa Klondyke. El estudio fue conducido en el mes de Febrero del año 1991 a Septiembre de 1993. El alimento preferido fue determinado basado en la frecuencia que ocurrio en 370 ejemplos de escrementos y los resultados fueron los siguientes porcentajes: $\mathbf{4 8 \%}$ Venado (Cola-Blanca y Venado Mula Odocoileus spp.), 34\% Ganado Vacuno, $17 \%$ Cochi Javalin (Tayassu tajacu), $6 \%$ Conejo (Sylvilagus spp) y Liebre Lepus californicus), $4 \%$ Roedor y $2 \%$ Borrego del Decierto (Ovis canadensis mexicanus). Tambien fue estimado el porcentaje de biomasa y la proporción de especies casadas y consumidas por León de Montaña En cuanto al respecto de biomasa consumida, Ganado Vacuno fue $44 \%$, Venado $40 \%$, Cochi Javalin 10.9\%, conejos $2.9 \%$, y roedores $0.02 \%$. De acuerdo con el promedio de peso de presa consumida por el León de Montaña la proporción de especies consumidas cambio a lo siguiente: $52.7 \%$ Conejo, $\mathbf{1 6 . 3 \%}$ Venado, $\mathbf{1 2 \%}$ Roedores, $10 \%$ Cochi Javalin, 8\% Ganado Vacuno, 0.5\% Borrego del Decierto. Tambien fue estimada la cantidad de diferente especies que pudieran existir en esta misma area usando un Helicoptero en 4 diferente vuelos, las siguientes especies fueron encontradas: (Venado, Ganado Vacuno, y Cochi Javalin ). En los resultados observamos que el León de Montaña selecciono Venado con menos frequencia, comparado con la fiques sugerida, Ganado Vacuno (Crias ) fue poco mas seleccionado de lo esperado, y Cochi Javalin como se esperaba. Especulamos que Leónes de Montaña seleccionarón Ganado Vacuno (Crias), porque fue mas vulnerable a la casa del León de Montaña que de lo que fue el Venado.

mountain lions. From 1987 through 1989, 57 mountain lions were killed within a 100,000 ha area. Ensuing public articles resulted in negative criticism of the control operation (B. Burkhart: Rancher, U.S. hunters kill wildlife without rein by State. Arizona Republic, June 15, 1989). We initiated an investigation of mountain lion-livestock interactions in the Aravaipa-Klondyke area of southeast Arizona. A main objective was to determine if mountain lions in the area selected livestock and other prey in proportion to availability. 


\section{Study Area}

The Aravaipa-Klondyke study area (AKSA) consisted of 95,100 ha which included Aravaipa Canyon, portions of the Aravaipa Creek watershed, Galiuro Mountains, and the San Carlos Apache Indian Reservation (Fig. 1).

Elevations on the study area ranged from 750 to $2,300 \mathrm{~m}$. Topography within all mountain ranges was steep and broken, with stone pinnacles, narrow and deep canyons, and rugged cliffs common at higher elevations. These formations merged downslope to comparatively level terraces near the bajadas of the Aravaipa Valley to the east, the Gila River Basin to the north, and the San Pedro River to the west.

The study area climate typified that of southeastern Arizona (Lowe 1964). Mean temperatures ranged from 8 to 26 $\mathrm{C}$, and precipitation averaged $31.6 \mathrm{~cm}$ per year. Annual spring droughts were usually followed by late summer thunderstorms (monsoons) produced by moisture from the Gulf of Mexico. Winter rains were less episodic and more widespread, originating from Pacific fronts. Snowfall in the area was infrequent at higher elevations and rare in the lower valley areas.

The study area had a wide diversity of vegetation types. Seven of Brown and Lowe's (1974) biotic communities occurred in the study area; semidesert grassland (40\% of area), Arizona upland Sonoran desert scrub (30\%), interior chaparral (14\%), Madrean evergreen woodland (13\%), Great Basin conifer woodland $(2 \%)$, petran montane conifer forest $(<1 \%)$, and riparian strips along streams.

\section{Livestock and Prey Occurrence}

Both historic and current livestock operations on the study area could affect mountain lion diets. Beginning in the $1870 \mathrm{~s},>50,000$ cattle $\left(>125 / \mathrm{km}^{2}\right)$ annually occupied the Aravaipa Valley. Cattle numbers were reduced after significant drought in the late 1890's, but were still grazed in larger numbers than today. By the 1920's, an additional 40,000 angora goats grazed the rougher parts of the Aravaipa watershed and 2,000 burros and 1,800 horses ran free (Hadley et al. 1991).

Grazing pressure declined during the 1930's. The value of mohair decreased,

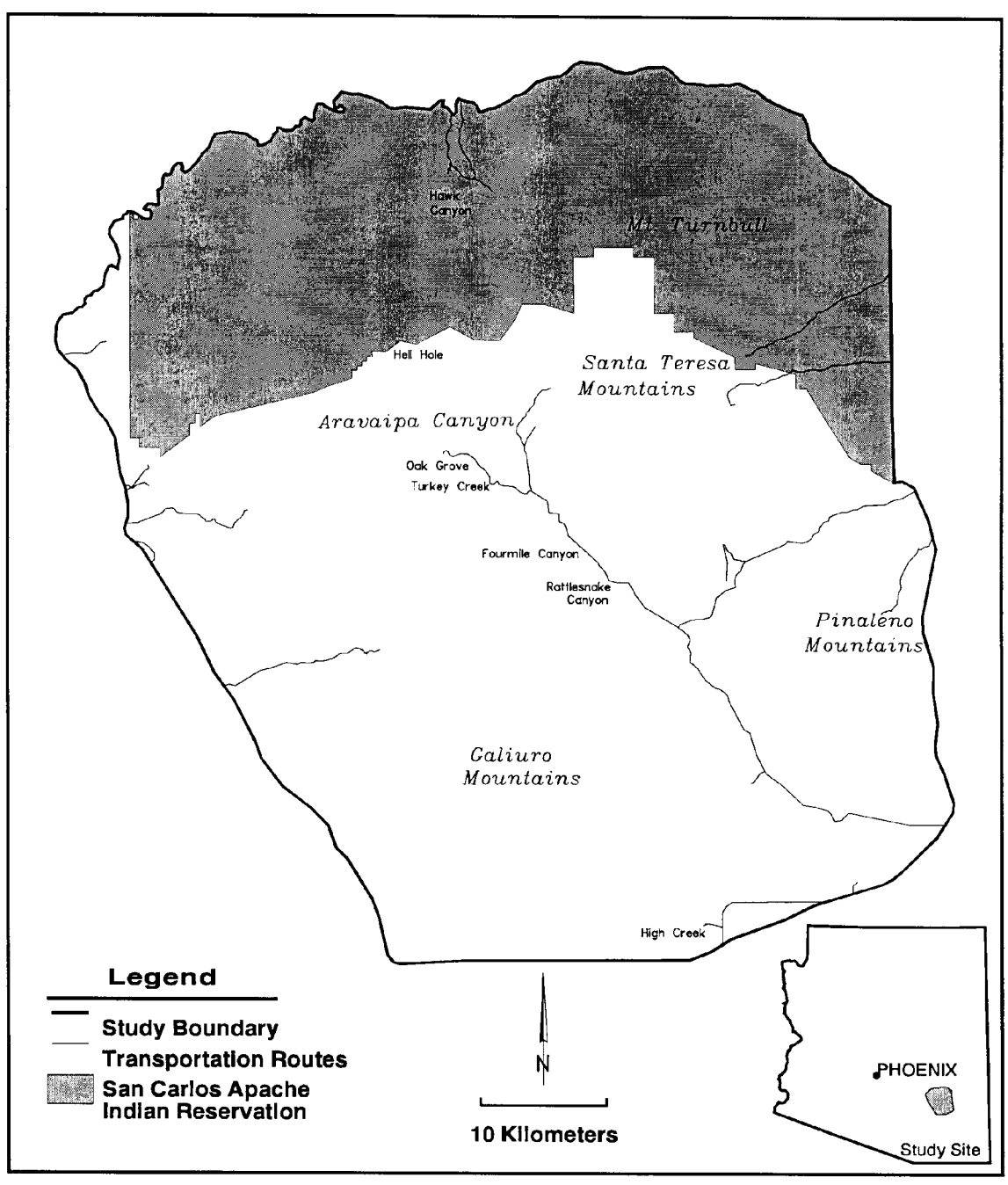

Fig. 1. Boundaries of the Aravaipa-Klondyke study area where mountain lion diet selection was studied, 1991-1993.

leading to removal of most goats by 1940. The Federal government passed the Taylor Grazing Act in 1934, which called for removal of wild horses, fencing of public lands, and reductions (>50\% in some areas) in the numbers of cattle grazed. During our study, there were 22 cattle grazing allotments on public lands (Commercial livestock area) with no restrictions on the San Carlos Indian Reservation (Fig. 1).

Wildlife has also varied in abundance on the study area during the past century. Hadley et al. (1991) reported that Apaches complained about the scarcity of game shortly after 1900. Large wild mammals remained scarce for another 2-3 decades, then began to increase. Based on interviews with local residents and natural resource managers, deer populations were larger during the peri- od from the 1940s to the late 1960s than they were afterward.

Javelina populations have recently declined in the study area, but reasons for the decline were not well understood (Cunningham et al. 1995). Desert bighorn sheep were extirpated in the 1930's. In 1973, 22 bighorn sheep were reintroduced into the area and the population increased to $>100$ by 1985 (Cunningham et al. 1993).

\section{Methods}

\section{Prey Availability}

Densities of deer, calves and adult cattle, and javelina within the study area were estimated 4 times: October 1991, April and October 1992, and April 1993. We conducted aerial surveys for 4 days 
each estimate from a Bell Jet-Ranger helicopter along 52 10-km nonoverlapping transects following procedures of Anderson et. al. (1979) and Burnham et al. (1980). Transects were oriented at right angles to major drainages and were flown at an airspeed of $48 \mathrm{~km} / \mathrm{hr}$ at $30 \mathrm{~m}$ altitude. Front and rear observers positioned on the right side of the helicopter made independent counts of prey species by group size up to $180 \mathrm{~m}$ from the helicopter. Cattle were divided into 2 groups based on size; calves $(<180 \mathrm{~kg}$ ) versus adults (>180 kg).

Based on line transect procedures, we had to assume equal visibility of the 3 key prey species (deer, javelina, and cattle). However our qualitative observations were that deer and javelina were not as visible as cattle in thicker vegetation at distances $>100 \mathrm{~m}$ from the helicopter. This bias could result in lower deer and javelina density estimates and higher cattle density estimates than really existed.

Population density estimates were calculated using TRANSECT II software (Laake et al. 1979) as recommended by Burnham et al. (1980). Prey numbers among surveys and between the commercial livestock and San Carlos Indian Reservation portions of the study area were compared using MANOVA.

\section{Prey Consumption and Selection}

Two mountain lion scats were collected each month within 8 equal-sized subdivisions of the study area. We searched for scat by hiking or riding horseback along ridges and washes in each subdivision. We identified mountain lion scats by size and shape (Murie 1954); only scats $>30 \mathrm{~mm}$ in diameter were collected which excluded most coyote (Canis latrans) and bobcat (Felis rufus) scats (Danner and Dodd 1982). Scats were judged to be $<1$ month old when dark and moist and were labeled as fresh; all others were labeled as old. While searching for scat, we also identified fresh $(<1$ month old) mountain lion kills by criteria described by Shaw (1989).

Prey items in scats were identified on basis of hair and skeletal remains. Scats were soaked in water and washed through 1- and 3-mm sieves. Skeletal material was compared with known reference materials. Hair was examined microscopically and compared with reference slides and photomicrographs from Moore et al. (1974). We did not differentiate between white-tailed and mule deer hair, or between cottontail and jackrabbit, or among rodent species.

We used frequency of occurrence data to estimate the relative number of each taxonomic group that were eaten using procedures described by Ackerman et al. (1984). Weights of white-tailed and mule deer were estimated from average live weights measured at deer hunt check stations near the study area (R. Olding, Ariz. Game and Fish Dept., unpubl. data). Weights of other species were from Burt and Grossenheider (1964).

Kill estimates were divided into 2 seasons; March-August (spring-summer) and September-February (fall-winter). We then analyzed diet versus availability when calf numbers were high and low. Scats considered fresh were pooled across years to increase sample size.

We compared estimates of abundance (i.e., availability) of deer, calves, and javelina with numbers estimated eaten by mountain lions (i.e.,use). We used Chi-square contingency tables to test for differences between prey use and availability by season and overall. If differences $(\mathrm{P}<0.05)$ existed, Bonferroni confidence intervals were used to indicate in which instances use did not equal availability (Neu et al. 1974, Byers et al. 1984). For significant Bonferroni confidence intervals we used Jacobs' D selectivity index (Jacobs 1974) to indicate direction and magnitude of selection or avoidance of prey.

\section{Results}

\section{Prey Availability}

Overall, deer were the most abundant prey species surveyed in the study area (Table 1). Deer numbers were higher in fall (post-fawning) than spring. Calf numbers were higher in spring than fall as most calving occurred from December to February. Javelina numbers were relatively stable among the first 3 surveys, but were lower in April 1993. The number of javelina groups seen on the San Carlos Indian Reservation were too small to allow density estimation.

Prey densities (all species combined) were higher on the commercial livestock portion of the study area than on the Reservation $(\mathrm{P}=0.043)$. However, there were no differences in relative proportions of prey species between the commercial and reservation areas and data sets were pooled.

\section{Prey Selection}

We found 41 mountain lion kills which included 16 white-tailed deer, 7 mule deer, 10 cattle, 4 javelina, and 4 desert bighorn sheep. Male:female ratio

Table 1. Large prey densities within the Aravaipa-Klondyke study area, Arizona, 1991-93, as determined by helicopter surveys.

\begin{tabular}{|c|c|c|c|c|c|c|c|c|}
\hline \multirow[t]{2}{*}{$\begin{array}{l}\text { Area } \\
\text { Date }\end{array}$} & \multicolumn{2}{|c|}{$\begin{array}{l}\text { Calves } \\
(<180 \mathrm{~kg})\end{array}$} & \multicolumn{2}{|c|}{$\begin{array}{l}\text { Adult cattle } \\
(>180 \mathrm{~kg})\end{array}$} & \multicolumn{2}{|c|}{ Deer } & \multicolumn{2}{|c|}{ Javelina } \\
\hline & \multicolumn{2}{|c|}{$95 \% \mathrm{CI}$} & \multicolumn{2}{|r|}{$95 \% \mathrm{CI}$} & \multicolumn{2}{|r|}{$95 \% \mathrm{CI}$} & \multicolumn{2}{|r|}{$95 \% \mathrm{CI}$} \\
\hline $\begin{array}{l}\text { Commercial } \\
\text { livestock portion }\end{array}$ & \multicolumn{8}{|c|}{ 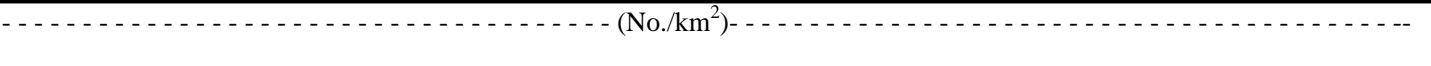 } \\
\hline Oct 1991 & 0.6 & $0.4-1.0$ & 1.7 & $1.0-2.8$ & 6.1 & $0.5-8.1$ & 2.5 & $1.7-3.7$ \\
\hline Apr 1992 & 1.2 & $0.9-1.8$ & 5.1 & $4.3-6.0$ & 5.5 & $4.3-7.1$ & 2.7 & $1.9-3.7$ \\
\hline Oct 1992 & 0.6 & $0.0-2.0$ & 1.7 & $0.0-62.9$ & 6.9 & $5.4-8.8$ & 2.9 & $0.1-77.0$ \\
\hline Apr 1993 & 2.0 & $1.6-2.4$ & 4.8 & $4.2-5.5$ & 2.7 & $2.1-3.5$ & 0.6 & $0.4-1.0$ \\
\hline $\bar{x}$ & 1.1 & & 3.3 & & 5.3 & & 2.2 & \\
\hline \multicolumn{9}{|c|}{ San Carlos Indian Reservation } \\
\hline Oct 1991 & 0 & $0-0$ & 0.4 & $0.2-0.9$ & 3.6 & $2.6-4.9$ & 0 & $0-0$ \\
\hline Apr 1992 & 2.3 & $0.0-56.5$ & 1.8 & $1.2-2.8$ & 2.5 & $1.5-4.1$ & 27.5 & $0.3-2.7$ \\
\hline Oct 1992 & 0.03 & $0.0-0.3$ & 0.1 & $0.0-0.4$ & 2.5 & $1.6-3.8$ & 0.6 & $0.3-1.0$ \\
\hline Apr 1993 & 0.05 & $0.0-0.9$ & 1.8 & $1.0-3.3$ & 6.3 & $4.3-9.4$ & 0 & $0-0$ \\
\hline $\bar{x}$ & 0.6 & & 1.0 & & 3.7 & & & \\
\hline
\end{tabular}


Table 2. Diet of mountain lions, based on the analysis of $\mathbf{3 7 0}$ scats, from the Aravaipa-Klondyke Study Area, Arizona, 1991-93. Percent biomass and relative number of individuals estimated consumed by mountain lions are calculated according to Ackerman et al. (1984).

\begin{tabular}{|c|c|c|c|c|c|}
\hline Prey species & $\begin{array}{c}\text { (A) } \\
\text { Frequency } \\
\text { of } \\
\text { occurrence }\end{array}$ & $\begin{array}{c}\text { (B) } \\
\text { Estimated } \\
\text { weights of } \\
\text { individuals }\end{array}$ & $\begin{array}{l}\text { Correction } \\
\text { factor }\end{array}$ & $\begin{array}{c}\text { Biomass } \\
\text { consumed }^{2}\end{array}$ & $\begin{array}{c}(\mathrm{E}) \\
\text { Relative } \\
\text { number of } \\
\text { individuals } \\
\text { consumed }\end{array}$ \\
\hline & $(\%)$ & $(\mathrm{kg})$ & $(\mathrm{kg} / \mathrm{scat})^{1}$ & $(\%)$ & $(\%)^{3}$ \\
\hline Deer & 0.48 & 44 & 3.52 & 40.1 & 16.6 \\
\hline Calves & 0.34 & 100 & 5.48 & 44.2 & 8.0 \\
\hline Javelina & 0.17 & 20 & 2.68 & 10.9 & 10.0 \\
\hline Rabbit & 0.06 & 1 & 2.02 & 2.9 & 52.8 \\
\hline Rodent & 0.04 & 0.03 & 0.03 & 0.02 & 12.0 \\
\hline Desert bighorn & 0.02 & 50 & 3.73 & 1.8 & 0.5 \\
\hline
\end{tabular}

${ }^{1}$ Estimated weight of prey consumed per collectible scat produced, when such prey is the only item in the scat $(\mathrm{C}=$ $1.98+0.035 \mathrm{~B})$.

${ }^{2} \mathrm{D}=(\mathrm{A} \times \mathrm{C}) / \sum(\mathrm{A} \times \mathrm{C})$

${ }^{3} \mathrm{E}=(\mathrm{D} \div \mathrm{B}) / \sum(\mathrm{D} \div \mathrm{B})$

was almost equal for white-tailed deer kills, but all mule deer kills were females. We found no deer fawn or juvenile javelina kills, but 3 of 4 bighorn sheep kills were lambs. Nine of 10 killed cattle were calves, and one was an adult cow; evidence indicated she was killed at the same time as her calf. Of the calves we found and 7 additional ones reported by ranchers, 8 were estimated $<4$ months of age, and 8 were estimated $>4$ months of age.

Deer remains were found in $48 \%$ of 370 scats and cattle remains occurred in $34 \%$ (Table 2). Javelina was the next most commonly-encountered food item (i.e., 17\%), followed by rabbits, rodent, and desert bighorn sheep. Other prey such as birds, badger (Taxidea taxus), black bear (Ursus americanus), porcupine (Erethizon dorsatum), and skunk (Mephitis spp.) occurred in very few scats. Converted to biomass, diet of mountain lions was dominated by cattle $(44 \%)$ and deer $(40 \%)$. Javelina com- prised $10.9 \%$ of the biomass, and rabbits, rodents, and bighorn sheep all comprised $<3 \%$.

Neither frequency of prey nor estimated biomass accurately reflected number of individual prey items eaten. Rabbits were the most frequently killed prey item, followed by deer, rodents, javelina, cattle, and desert bighorn.

During both seasons, rabbits were killed and eaten more than any other prey, but calves composed the majority of the biomass eaten (Table 3). During March-August (spring-summer), small prey (rabbits and rodents) were killed most frequently and were a greater proportion of the mountain lion diet than during September-February. The number of individual deer, calves, and javelina consumed in September-February (fallwinter) all increased more than $100 \%$ over spring-summer. Rabbits were still the most frequently killed prey in fallwinter, but the estimate of number of individuals consumed decreased $31.6 \%$.
Over the entire study, mountain lions in the study area ate fewer deer than expected based on deer availability, slightly more calves than expected, and javelina in proportion to availability (Table 4). During the fall-winter season, mountain lions consumed fewer deer than expected, but consumed calves and javelina in proportion to availability. During the spring-summer season, all 3 species were consumed as expected based on availability.

\section{Discussion}

\section{Prey Use}

In our study, rabbits were the most numerous food item. Deer are the principal prey of mountain lions in many other areas based on frequency of occurrence in scats (Anderson 1983). Our data suggest that the importance of rabbits, rodents, or other small prey are masked by just using frequency of occurrence without a conversion factor. Studies where mountain lion kills are used for diet determination would also underrate small animals as most mountain lions would consume the whole animal. Also, Johnson and Aldred (1982) found that bobcats digested more bones and hair of smaller prey over larger prey. Mountain lions may digest almost all bones and hair of small species.

Based on the Ackerman et al. (1986) caloric needs model, and individual prey proportions eaten by mountain lions on the study area, we estimated the numbers of prey eaten each year. A resident female with 3 kittens would eat 35-40 deer, 17-19 calves, 21-24 javelina, 90-100 rabbits, 20-23 rodents, and 1-2 desert bighorn sheep. A resident female without kittens would eat 9-11 deer,

Table 3. Seasonal diet based on frequency of occurrence, percent biomass, and relative numbers of individuals consumed by mountain lions in the Aravaipa-Klondyke study area, Arizona, 1991-93.

\begin{tabular}{|c|c|c|c|c|c|c|}
\hline & \multicolumn{3}{|c|}{$\begin{array}{l}\text { March-August } \\
\quad(n=82)\end{array}$} & \multicolumn{3}{|c|}{$\begin{array}{c}\text { September-February } \\
(\mathrm{n}=54)\end{array}$} \\
\hline & $\begin{array}{l}\text { Frequency } \\
\text { of } \\
\text { occurrence }\end{array}$ & $\begin{array}{l}\text { Biomass } \\
\text { consumed }\end{array}$ & $\begin{array}{l}\text { Number of } \\
\text { individuals } \\
\text { consumed }\end{array}$ & $\begin{array}{l}\text { Frequency } \\
\text { of } \\
\text { occurrence }\end{array}$ & $\begin{array}{l}\text { Biomass } \\
\text { consumed }\end{array}$ & $\begin{array}{l}\text { Number of } \\
\text { individuals } \\
\text { consumed }\end{array}$ \\
\hline & \multicolumn{6}{|c|}{ 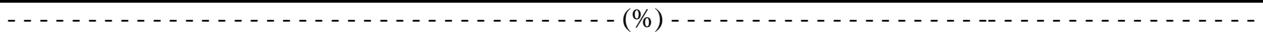 } \\
\hline Deer & 36.6 & 33.2 & 8.6 & 44.4 & 37.9 & 21.0 \\
\hline Calves & 36.6 & 51.7 & 5.9 & 33.3 & 44.3 & 10.8 \\
\hline Javelina & 11.0 & 7.5 & 4.4 & 22.2 & 14.3 & 17.7 \\
\hline Rabbit & 12.2 & 6.5 & 73.3 & 3.7 & 1.7 & 41.7 \\
\hline Rodent & 4.9 & 0.02 & 7.5 & 1.9 & 0.01 & 8.0 \\
\hline Bighorn & 1.2 & 1.0 & 0.2 & 1.9 & 1.7 & 0.7 \\
\hline
\end{tabular}


Table 4. Selection of 3 prey species by mountain lions based on frequency of occurrence in mountain lion scats and proportion available as determined from aerial surveys, Aravaipa-Klondyke Study Area, Arizona, 1991-93. (Rabbits, rodents, and desert bighorn sheep were not recorded during surveys).

\begin{tabular}{lccccc}
\hline \hline Season & $\begin{array}{c}\text { Frequency of } \\
\text { occurrence }\end{array}$ & $\begin{array}{c}\text { Relative } \\
\text { number of } \\
\text { individuals } \\
\text { consumed }\end{array}$ & $\begin{array}{c}\text { Proportion } \\
\text { of prey } \\
\text { species } \\
\text { available }\end{array}$ & $\begin{array}{c}\text { Bonferroni } \\
95 \% \text { CI }\end{array}$ & Jacobs' D ${ }^{1}$ \\
\hline $\begin{array}{l}\text { Year-long diet } \\
\text { Deer }\end{array}$ & 48 & 47.3 & 58.0 & $0.41-0.54$ & -0.22 \\
$\begin{array}{l}\text { Calves } \\
\text { Javelina }\end{array}$ & 34 & 23.2 & 17.8 & $0.18-0.28$ & 0.16 \\
Fall diet & 17 & 29.5 & 24.1 & $0.24-0.35$ & \\
Deer & & & & & -0.40 \\
Calves & 47 & 42.6 & 63.1 & $0.27-0.59$ & \\
Javelina & 24 & 21.8 & 10.7 & $0.08-0.35$ & \\
Spring diet & & 35.6 & 26.2 & $0.2-0.51$ & \\
Deer & 44 & 45.8 & 52.7 & $0.33-0.59$ & \\
Calves & 44 & 31.2 & 25.8 & $0.19-0.43$ & \\
Javelina & 13 & 22.9 & 21.5 & $0.12-0.34$ & \\
\hline
\end{tabular}

${ }^{1}$ A positive number means the item was selected for; a negative number means the item was selected against (Range $=$ 1.0 to +1.0$)$.

5-6 calves, 8-11 javelina, 7-9 rabbits, $5-7$ rodents, and $<1$ desert bighorn sheep per year, while a resident male would eat 14-18 deer, 7-9 calves, 9-11 javelina, 36-46 rabbits, 8-11 rodents, and < 1 bighorn sheep per year. Ackerman et al. (1986) estimated that young female or male transients would consume approximately $50 \%$ the prey of a resident female without kittens.

We estimated that mountain lions killed >600 deer and >225 calves each year on the study area (including both the commercial livestock and San Carlos Indian Reservation portions). If our deer kill estimates were accurate, we should have observed a reduction in deer numbers, but this did not occur. Conversations with ranchers suggested they believed livestock losses, though substantial, were not $>225$.

Several studies (see Ackerman et al. 1986 for review) have estimated that mountain lions kill a deer at 4 to 20 day intervals, depending on sex and age of prey. Although mountain lions have the ability to kill ungulate prey frequently, we suggest they may not do so if they opportunistically feed on smaller prey. However, this would be difficult to evaluate, and would require intense 24-hour tracking without affecting lion behavior.

\section{Interaction with Cattle}

Cattle, except for calves, are larger than most mountain lion prey. Prey selection is influenced by both prey availability and vulnerability (Sunquist and Sunquist 1989, Iriate et al. 1990). Only in Arizona have mountain lions been reported to prey heavily (>30\% diet) on cattle (Tully 1991, Cunningham et al. 1995). Most reports come from mid-elevation chaparral and pine-oak woodlands in central Arizona; few cases have been documented in high-elevation or low desert areas (Shaw et al. 1988). In central Arizona, Shaw (1977) found cattle to comprise at least $37 \%$ of the mountain lion kills, and cattle remains occurred in $34 \%$ of the scats he analyzed; cattle kills peaked in spring.

Estimates of prey densities compared with mountain lion diet suggested that calves were selected by mountain lions in preference to deer. Deer densities in chaparral and forest vegetation types were probably higher than we estimated because of poor visibility during helicopter surveys. If correct, this bias would make mountain lion selection for calves over deer greater than our calculations suggested.

We speculate that calves were more vulnerable to mountain lion predation than deer. Hereford or crossbreed calves are more visible in thick or open terrain while deer are cryptically colored, quiet, and spend most of the day hiding. Deer are more alert and wary than calves. When we followed mountain lion travel routes we observed more calves than deer or javelina while prey surveys suggested deer and javelina densities were greater.
Shaw (1981) suggested that increasing the deer:calf ratio may reduce cattle predation by mountain lions. However, we suggest that calf vulnerability was the major factor influencing kill rates, and increases in the deer prey base may not affect kill rates on calves. Also, changes in deer and javelina populations are highly influenced by climatic factors which are impossible for wildlife managers to control.

Shaw (1981) reported that the majority of calves killed were <4-months old and that calf predation was seasonal. We found mountain lions killed and ate calves of all ages year round. This also suggests that moderate increases in deer numbers (fall fawning period in our study) are unlikely to cause appreciable reduction in mountain lion predation on calves.

In our study area, many allottees have nowhere to graze cattle except in rugged terrain with relatively dense vegetation cover. Those with sufficient flat, open pasture hold their younger calves out of rugged areas as long as possible and generally experience fewer losses to mountain lions. Those without lower pastures experience greater losses of calves to mountain lions.

We believe that mature male mountain lions, rather than females and immatures, caused most of the livestock losses. During the study and statewide since 1990, females were killed in depredation control cases only during periods when small calves were abundant, and only 1 mountain lion <24 months of age was killed in connection with a depredation case (Cunningham et al. 1995). Although males are easier to catch than females (Anderson 1983), current strict controls on snaring and allowing dog hunting only in the vicinity of the kill increase the chance of killing the offending animal.

Anderson (1983) reported that male mountain lions weighed approximately 1.4 times more than females. Iriate et al. (1990) found that there was a positive correlation $(r=0.875)$ between mountain lion body size and prey size selected. Kruuk (1986) reported that felids are strictly carnivorous and select prey commensurate with their own body size. If mature males killed most of the livestock in this study, then our estimates of potential livestock losses to females with kittens were probably high. Also, additional bias may have occurred 
because we restricted scat collections to scats $>30 \mathrm{~mm}$ in diameter; such scats may have been more representative of large lions. Regardless, our estimates indicate the potential for large economic losses from mountain lion predation.

\section{Literature Cited}

Ackerman, B.B., F.G. Lindzey, and T.P. Hemker. 1984. Cougar food habits in southern Utah. J. Wildl. Manage. 48:147-155.

Ackerman, B.B., F.G. Lindzey, and T.P. Hemker. 1984. Predictive energetics model for cougars. Pp 333-352 In: S.D. Miller and D.D. Everett, eds. Cats of the world: biology, conservation and management. Nat. Wildl. Fed., Washington, D.C.

Anderson, A.E. 1983. A critical review of literature on puma (Felis concolor). Colo. Div. Wildl. Spec. Rep. 54, Denver, Colo. 91pp.

Anderson, D.R., J.L. Laake, B.R. Crain, and K.P. Burnham. 1979. Guidelines for line transect sampling of biological populations. J. Wildl. Manage. 43:70-78.

Barnes, C.T. 1960. The cougar or mountain lion. The Ralton Co., Salt Lake City, Ut. 176pp.

Brown, D.E. and C.H. Lowe. 1974. A digitized computer-compatible classification for natural and potential vegetation in the Southwest with particular reference to Arizona. J. Ariz.-Nev. Acad. Sci. 9 (suppl. 2): 1-11.

Burt, W.H. and R.P. Grossenheider. 1964. A field guide to mammals. Houghton Mifflin Co., Boston, Mass. 284 pp.

Burnham, K.P., D.R. Anderson, and J.L. Laake. 1980. Estimation of density from line transect sampling of biological populations. Wildl. Monogr. 72.202 pp.

Byers, C.R., R.K. Steinhorst, and P.R. Krausman. 1984. Clarification of a technique for analysis of utilization-availability data. J. Wildl. Manage. 48:1050-1053.

Christensen, G.L. and R.S. Fisher, editors. 1976. Transactions of the mountain lion workshop. U.S. Fish and Wild. Serv. and Nev. Div. Wild., Sparks. 213pp.

Cunningham, S.C., N. Dodd, and R. Olding. 1993. Arizona's bighorn sheep reintroduction program. Pp. 203-239 In: $\mathrm{R}$. Lee, ed. The desert bighorn sheep in Arizona. Ariz. Game and Fish Dept., Phoenix, Ariz.

Cunningham, S.C., L.A. Haynes, C. Gustavson, and D.D. Haywood. 1995. Evaluation of the interaction between mountain lions and cattle in the AravaipaKlondyke area of southeast Arizona. Ariz. Game and Fish Dep. Tech. Rep. 17 Phoenix, Ariz. 64 pp.
Danner, D.A. and N.L. Dodd. 1982. Comparison of coyote and gray fox scat diameters. J. Wildl. Manage. 46:240-241.

Hadley, D., P. Warshall, and D. Bufkin. 1991. Environmental change in Aravaipa, 1870-1970: an ethnoecological survey. U.S. Bur. Land Manage. Cultural Res. Ser. No. 7. Safford, Ariz. 368 pp.

Iriate, J.A., W.L. Franklin, W.E. Johnson, and K.H. Redford. 1990. Biogeographic variation of food habits and body size of the American puma. Oecologia 85:185-190.

Jacobs, J. 1974. Quantitative measurements of food selection. Oecologia 1:413-417.

Johnson, M.K. and D.R. Aldred. 1982. Mammalian prey digestibility by bobcats. J. Wildl. Manage. 46(2):1982.

Kruuk, H. 1986. Interactions between Felidae and their prey species: a review. Pp 353-374 In: S.D. Miller and D.D. Everett, eds. Cats of the world: biology, conservation and management. Natl. Wildl. Fed., Washington D.C.

Laake, J.L., K.P. Burnham, and D.R. Anderson. 1979. User's manual for program TRANSECT. Utah State Univ. Press, Logan, Ut. 26 pp.

Lowe, C.H. 1964. The vertebrates of Arizona. Univ. Arizona Press, Tucson, Ariz. 270 pp.

Moore, T.O., L.D. Spence, C.E. Dugnolle, and W.G. Hopworth. 1974. Identification of the dorsal guard hairs of some mammals of Wyoming. Wyo. Game and Fish Dept. Bull. No. 14. 117 pp.

Murie, O.J. 1954. A field guide to animal tracks. Houghton-Mifflin Co., Boston, Mass. 374 pp.

Nowak, R.M. 1976. The cougar in the United States and Canada. U.S. Fish and Wildl. Serv., Washington, D.C., and New York Zool. Soc., New York, N. Y. 190 pp.

Neu, C.W., C.R. Byers, and J.M. Peek. 1974. A technique for analysis of utilization-availability data. J. Wildl. Manage. 38:541-545.

Shaw, H.G. 1977. Impacts of mountain lion on mule deer and cattle in northwestern Arizona. Pp 306-318 In: R.L. Phillips and C. Jonkel, eds. Proc. 1975 predator symp., Univ. Montana, Missoula, Mont.

Shaw, H.G. 1981. Comparison of mountain lion predation on two study areas in Arizona. Pp 306-318 In: Proc. Wildl. livestock relationships symp. Univ. Idaho Forest Wildl., and Range Exp. Sta., Moscow, Ida.

Shaw, H.G. 1989. Mountain lion field guide. Fourth ed. Ariz. Game and Fish Dept. Spec. Rep. 9, Phoenix, Ariz 47 pp.

Shaw, H.G., N.G. Woolsey, J.R. Wegge, and R.L. Day, Jr. 1988. Factors affecting mountain lion densities and cattle depredation in Arizona. Ariz. Game and Fish Dept. Final Report, P-R Proj. W-78-R, Work Plan 2, Job 29, Phoenix, Ariz. 16 pp.
Sunquist, M.E. and F.C. Sunquist. 1989. Ecological constraints on predation by large felids. Pp 283-301 In: J. L. Gittleman, ed. Carnivore behavior, ecology and evolution. Cornell Univ. Press. Ithaca, N.Y.

Tully, R.J. 1991. Results, 1991 questionnaire on damage to livestock by mountain lion. Pp. 68-74 In: C. E. Braun, ed. Proc. mountain lion-human interaction symp., Colo. Div. Wildl., Denver, Colo. 